\title{
Halogen-based reconstruction of Russian Arctic sea ice area from the Akademii Nauk ice core (Severnaya Zemlya)
}

\author{
A. Spolaor ${ }^{1,2}$, T. Opel ${ }^{3}$, J. R. McConnell ${ }^{4}$, O. J. Maselli ${ }^{4}$, G. Spreen ${ }^{5}$, C. $\operatorname{Varin}^{1}$, T. Kirchgeorg ${ }^{1}$, D. Fritzsche ${ }^{3}$, \\ A. Saiz-Lopez ${ }^{6}$, and P. Vallelonga ${ }^{7}$ \\ ${ }^{1}$ Ca'Foscari University of Venice, Department of Environmental Sciences, Informatics and Statistics, Via Torino 155,30170 \\ Venice Mestre, Italy \\ ${ }^{2}$ Institute for the Dynamics of Environmental Processes, IDPA-CNR, Via Torino 155, 30170 Venice Mestre, Italy \\ ${ }^{3}$ Alfred Wegener Institute Helmholtz Centre for Polar and Marine Research, Periglacial Research Section, Telegrafenberg \\ A43, 14473 Potsdam, Germany \\ ${ }^{4}$ Desert Research Institute, Department of Hydrologic Sciences, 2215 Raggio Parkway, Reno, NV 89512, USA \\ ${ }^{5}$ Norwegian Polar Institute, Fram Centre, Hjalmar Johansens gt. 14, 9296 Troms $\emptyset$, Norway \\ ${ }^{6}$ Atmospheric Chemistry and Climate Group, Institute of Physical Chemistry Rocasolano, CSIC, 28006 Madrid, Spain \\ ${ }^{7}$ Centre for Ice and Climate, Niels Bohr Institute, University of Copenhagen, Juliane Maries Vej 30, \\ Copenhagen $\varnothing 2100$ Denmark
}

Correspondence to: A. Spolaor (andrea.spolaor@unive.it)

Received: 26 May 2015 - Published in The Cryosphere Discuss.: 24 August 2015

Revised: 17 December 2015 - Accepted: 5 January 2016 - Published: 26 January 2016

\begin{abstract}
The role of sea ice in the Earth climate system is still under debate, although it is known to influence albedo, ocean circulation, and atmosphere-ocean heat and gas exchange. Here we present a reconstruction of 1950 to 1998 AD sea ice in the Laptev Sea based on the Akademii Nauk ice core (Severnaya Zemlya, Russian Arctic). The chemistry of halogens bromine (Br) and iodine (I) is strongly active and influenced by sea ice dynamics, in terms of physical, chemical and biological process. Bromine reacts on the sea ice surface in autocatalyzing "bromine explosion" events, causing an enrichment of the $\mathrm{Br} / \mathrm{Na}$ ratio and hence a bromine excess $\left(\mathrm{Br}_{\mathrm{exc}}\right)$ in snow compared to that in seawater. Iodine is suggested to be emitted from algal communities growing under sea ice. The results suggest a connection between $\mathrm{Br}_{\text {exc }}$ and spring sea ice area, as well as a connection between iodine concentration and summer sea ice area. The correlation coefficients obtained between $\mathrm{Br}_{\text {exc }}$ and spring sea ice $(r=0.44)$ as well as between iodine and summer sea ice $(r=0.50)$ for the Laptev Sea suggest that these two halogens could become good candidates for extended reconstructions of past sea ice changes in the Arctic.
\end{abstract}

\section{Introduction}

The rapid and unexpected decrease of Arctic sea ice during recent decades has highlighted the lack of knowledge regarding the mechanisms controlling sea ice growth and decay. Sea ice affects albedo by covering the relatively dark, energyabsorbing ocean waters with highly reflective ice (Francis et al., 2009). Sea ice formation is an important process for driving salinification of surface waters, thereby promoting convection in polar regions (Holland et al., 2001). Sea ice also is an efficient barrier between the ocean and atmosphere, limiting the effectiveness of ocean water to warm the polar atmospheric boundary layer, as well as limiting both the exhalation of $\mathrm{CO}_{2}$ from $\mathrm{CO}_{2}$-rich upwelling circum-Antarctic waters and the drawdown of atmospheric $\mathrm{CO}_{2}$ by downwelling surface waters (Dieckmann and Hellmer, 2010).

Satellite measurements have documented a rapid decrease in recent Arctic summer sea ice area (Comiso, 2011; Stroeve et al., 2007). During the last 10 years, the four lowest September sea ice minima of the last 35 years have been recorded (Arctic Sea-Ice Monitor - IJIS, www.ijis.iarc.uaf. edu), with the lowest sea ice area of 3.41 million $\mathrm{km}^{2}$ recorded on 16 September 2012. This is $47 \%$ of the av- 
erage sea ice minimum extent for the 1970-1990 period (7.2 million $\mathrm{km}^{2}$ ), but the latest ocean-atmosphere coupled climate models are unable to replicate the rapid pace of Arctic sea ice retreat (Turner et al., 2012). Such limitations may result from poor parameterization of key physical sea ice processes because the only record available is the relatively short 35-year period of satellite observations.

Accurate reconstruction of sea ice variability before the satellite epoch is important for understanding interactions between sea ice area and both the forcing and effects of climate changes (Wolff et al., 2006). These results also are important for improved model calibration. Many different approaches have been proposed to reconstruct sea ice extent variability. Sediments in marine cores reflect sources and so are used to show pathways of Arctic and sub-Arctic oceanic circulation (Darby, 2003). Ice-rafted debris in marine sediment records indicates the occurrence of floating ice (Lisitzin, 2002), while sea-ice-related paleoproductivity can be inferred from the accumulated remains of microscopic organisms and other biomarkers. Recently, highly branched isoprenoids $\left(\mathrm{IP}_{25}\right)$ in specific sea ice diatoms in sediment cores have also been proposed and applied as indicators of past sea ice variability (Belt et al., 2007; Müller et al., 2009; Xiao et al., 2013). Coastal records also help to understand the past dynamics of sea ice, producing a clear signal in both coastal sediments and landforms (Polyak et al., 2010). Additionally, integration of various paleoclimate archives and historical observations allows a broad reconstruction of past sea ice variability in the Arctic (Divine and Dick, 2006; Kinnard et al., 2011; Polyakov et al., 2003; Vinje, 2001). A weakness of the available reconstructions of past sea ice area and variability, extending back more than a century, is that they are characterized by poor temporal resolution and/or a limited regional significance.

Many atmospheric conditions are recorded at high temporal resolution in ice cores, such as dust deposition, temperature, solar radiation and atmospheric gas concentration (Wolff et al., 2010), and so they are employed extensively for reconstructing past climate (Petit et al., 1999). The absence of sufficiently reliable and specific proxies has limited their application to reconstructions of sea ice extent and variability. Methanesulfonic acid (MSA), a product of ocean algal emissions, has been used to reconstruct past sea ice changes from both Antarctic and Arctic ice cores (Curran et al., 2003; Isaksson et al., 2005); however MSA is unstable and remobilized in ice cores over centennial to millennial timescales (Röthlisberger et al., 2010). Sodium in ice cores reflects glacial-interglacial sea ice variability but on shorter timescales is strongly influenced by meteorology as well as competing sea ice and open-ocean emission sources (Abram et al., 2013; Levine et al., 2014).

Recent studies of the halogen elements bromine $(\mathrm{Br})$ and iodine (I) have shown potential for their use as proxies of polar sea ice area extent in both Antarctic and Arctic regions (Spolaor et al., 2014; Sturges and Barrie, 1988). Bromine is released into the atmosphere as a component of sea salt. An additional source comes from so-called "bromine explosions", which are defined as an autocatalytic sequence of chemical reactions able to generate gaseous bromine compounds such as $\mathrm{BrO}$ from bromide trapped in the sea ice (Pratt et al., 2013; Vogt et al., 1996). This is supported by satellite measurements in polar regions that show pronounced springtime increases in atmospheric $\mathrm{BrO}$ concentrations (Schonhardt et al., 2012) associated with sea ice presence. These so-called bromine explosions (Simpson et al., 2007, 2015) have the net effect of enriching Br beyond the seawater $\mathrm{Br} / \mathrm{Na}$ ratio in the snow deposits in the ice caps and subsequently ice cores (Spolaor et al., 2014; Sturges and Harrison, 1986; Sturges and Barrie, 1988). Some studies have found depleted $\mathrm{Br}$ compared to seawater abundances in coastal areas (de Gois et al., 2015; Barrie et al., 2001). However all measurements conducted on Arctic and Antarctic ice caps demonstrate a general enrichment of $\mathrm{Br}$ (Spolaor et al., 2014) compared to seawater abundances. Other processes can influence the $\mathrm{Br}$ excess detected in the snow; however previous findings suggest that bromine-related sea ice chemistry could be the major explanation.

Iodine emissions to the polar atmosphere mainly arise from oceanic biological production and formation of volatile organo-iodine compounds (Atkinson et al., 2012). Laboratory analyses suggest that sea salt iodine contributes less than $2 \%$ of total iodine deposition (Spolaor et al., 2013b; Sturges and Barrie, 1988). Although it has been discovered that atmospheric iodine around Antarctica is produced from algae growing on the underside of the relatively thin seasonal sea ice (Saiz-Lopez et al., 2007, 2015), satellite measurements do not show exceptional iodine activity above Arctic sea ice (Spolaor et al., 2014), which may be due to differences in sea ice conditions between both polar environments. In the Arctic, only above summer are sea ice satellites able to determine IO emissions. Arctic boundary layer observations show sporadic enhanced atmospheric IO concentrations related to the presence of ice-free open-ocean conditions (Mahajan et al., 2010).

Here we present halogen records of the Akademii Nauk (AN) ice core (Opel et al., 2013) from Severnaya Zemlya to assess their potential for the reconstruction of regional sea ice extent variability in the Russian Arctic and to provide a new regional-scale sea ice reconstruction, i.e., the easternmost record of the Arctic. Severnaya Zemlya is located in the marine boundary layer and is surrounded by Arctic winter sea ice. The AN ice core features annual resolution and hence can be used to produce a sensitive climate record for comparison to satellite, ship and land-based observations of sea ice area. Combined with other circumpolar ice caps, this location allows the possibility to produce localized sea ice reconstructions for the whole Arctic region. The bromine excess $\left(\mathrm{Br}_{\mathrm{exc}}\right)$ is expressed in terms of concentrations $\left(\mathrm{ng} \mathrm{g}^{-1}\right)$ and was calculated by subtracting the seawater component from the total bromine concentration using sodium as a seawa- 


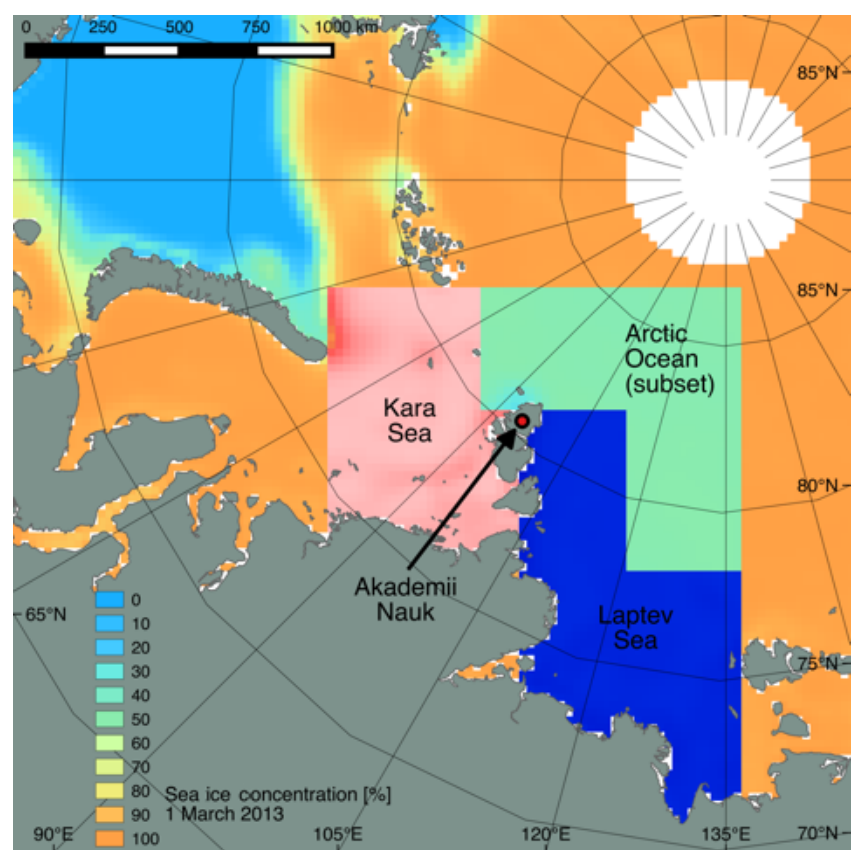

Figure 1. Arctic areas considered for sea ice calculations. Kara Sea (pink), Laptev Sea (dark blue) and a subset of the Arctic Ocean (green). The location of the Akademii Nauk ice core drill site on Severnaya Zemlya also is shown.

ter proxy. Iodine concentrations were used directly without any seawater correction since the seawater contribution (using the average seawater abundance) is less than $1 \%$. These halogen data were compared with summer and spring sea ice areas from the Laptev and Kara seas, the two Arctic seas east and west of Severnaya Zemlya, respectively. Our results suggest a strong connection between $\mathrm{Br}_{\mathrm{exc}}$ and spring sea ice changes in the Laptev Sea as well as a positive correlation between iodine and summer sea ice in the Laptev Sea. This work continues investigations already done by our research group on the connection between halogens (I, Br) and sea ice changes (Spolaor et al., 2013a, b). These data are the first investigating the halogen climate signal in the Arctic in the last 50 years and shed new light on the connections between halogen and past sea ice changes.

\section{Data and methods}

\subsection{Akademii Nauk ice core}

A $724 \mathrm{~m}$ ice core from the AN ice cap $\left(80^{\circ} 31^{\prime} \mathrm{N}, 94^{\circ} 49^{\prime} \mathrm{E}\right.$, $760 \mathrm{~m}$ a.s.l., Fig. 1) was drilled from 1999 to 2001 (Fritzsche et al., 2002), presenting the easternmost ice core record currently available from the Arctic. Due to the relatively low altitude of the ice cap, the ice core shows evidence of summer melt and infiltration processes (Opel et al., 2009) which may influence some of the atmospheric records preserved in the ice (Fritzsche et al., 2005). Despite a mean annual air temperature of $-15.7^{\circ} \mathrm{C}$ (May 1999 to April 2000), surface melting occurs almost every year when temperatures may rise above $0{ }^{\circ} \mathrm{C}$ even at the ice cap summit, and a considerable amount of the Akademii Nauk ice core consists of melt layers and partly infiltrated firn (Opel et al., 2009). In the literature few studies have reported the effect of meltwater percolation on the ice core climate signal. Pohjola et al. (2002) studied the effect of percolation in the Lomonosovfonna ice core (Svalbard), a site that features melting and infiltration conditions similar to the Akademii Nauk. Their results suggest that, though the original seasonal climate signal could be disturbed especially for the anions associated with strong acids $\left(\mathrm{NO}_{3}^{-}\right.$and $\left.\mathrm{SO}_{4}^{2-}\right)$, most of the other chemical species and in particular the stable water isotopes are less affected than the strong acids. In the Akademii Nauk ice core, stable isotope records still show seasonal variations, indicating a minor impact of melting and refreezing only. Even though ions and other species may be more affected, a deep infiltration and redistribution will be obstructed by the frequent occurrence of melt layers. Therefore, the Akademii Nauk ice core can be considered suitable for high-resolution (i.e., annual to multi-annual) reconstruction of paleoclimate and atmospheric aerosol loading as already shown for the past century (Weiler et al., 2005) and the past millennium (Opel et al., 2013). Bromine and iodine are photoactive species, but recent findings suggest that $\mathrm{Br}$ is preserved in the snow after deposition, while iodine can be remobilized in the snow but still maintains the average annual climatic signal (Spolaor et al., 2014). The relatively high average accumulation rate of $0.46 \mathrm{~m}$ water equivalent per year, determined for the period 1956-1999, could also help to preserve the halogen signal in the snowpack.

The core chronology is based on counting of annual layers in stable water isotopes, constrained by the identification of reference horizons including the ${ }^{137} \mathrm{Cs}$ nuclear bomb test peak (1963 AD) and volcanic eruptions (Bezymianny $1956 \mathrm{AD})$. In this pilot study, we focus on the core section 0-29 m, representing the time period 1950-1999. The core chronology for the time period viewed here is well constrained by the detection of the $1956 \mathrm{AD}$ volcanic eruption of Bezymianny (Kamchatka Peninsula) (Opel et al., 2013). Based on comparisons to other dating approaches (linear interpolation, age modeling) we estimate the dating uncertainties to be about \pm 1 year, and definitely less than \pm 3 years.

\subsection{Halogens analysis}

Contiguous, longitudinal samples $(1.0 \times 0.033 \times 0.033 \mathrm{~m})$ were cut from the Akademii Nauk ice core and shipped frozen to the Ultra-Trace Chemistry Laboratory at the Desert Research Institute for analyses using a unique, continuous ice core measurement system (McConnell et al., 2002). Longitudinal samples are melted consecutively on a carefully cleaned, engraved melter head that splits meltwater from different parts of the sample cross section into ultra-clean (in- 
nermost $\sim 10 \%$ ), clean (next $\sim 20 \%$ ) and potentially contaminated (outermost part of the ice core $\sim 70 \%$ ) continuously flowing sample streams. Elemental measurements are made on the ultra-clean sample stream, with ultra-pure nitric acid added immediately after the melter plate to yield an acid concentration of $\sim 1 \%$. The analytical system includes two Thermo-Fisher Element II high-resolution inductively coupled plasma mass spectrometers operating in parallel and used to measure simultaneously $>30$ elements (McConnell et al., 2014; Sigl et al., 2014), including Br, I, and Na; a Picarro L2130 water isotope analyzer (Maselli et al., 2013); a Droplet Measurement Technologies SP2 black carbon analyzer (McConnell et al., 2007); among other instruments for determination of ammonium, nitrate, hydrogen peroxide and other chemical compounds (Pasteris et al., 2014). Effective depth resolution differs between the instruments in the analytical system and operating parameters but in this study is estimated to be $\sim 0.02 \mathrm{~m}$ for $\mathrm{Br}, \mathrm{I}$, and $\mathrm{Na}$, with all measurements exactly co-registered in depth. Detection limits are 0.1 , 0.003 , and $0.06 \mathrm{ng} / \mathrm{g}$ for $\mathrm{Br}, \mathrm{I}$, and $\mathrm{Na}$, respectively.

\subsection{Back-trajectory calculations}

To understand the sources of air masses that influence the bromine and iodine deposition at the drill site of the Akademii Nauk ice core, we calculated back trajectories for the period covered by satellite sea ice measurements (1979-2000). Three-day back trajectories for spring (MarchApril-May; MAM) were chosen to investigate the bromine sources, while 6-day back trajectories for summer (JuneJuly-August; JJA) were chosen to investigate the iodine sources, where some long-life iodine organic compounds and recycling processes can influence total iodine concentrations (Simpson et al., 2015). Back trajectories were calculated with the model HYSPLIT (HYbrid Single-Particle Lagrangian Integrated Trajectory, Version September 2014) using NCEP/NCAR Reanalysis data from the National Weather Service's National Centers for Environmental Prediction provided by the NOAA's Air Resources Laboratory (Draxler and Hess, 1998). The arrival height was the drilling site at the Akademii Nauk ice cap located at $760 \mathrm{~m}$ a.s.l. Trajectories were calculated each $12 \mathrm{~h}$, and vertical motion mode was used. For a better comparison and an indicative estimation of the potential origin of air masses, back trajectories of 5-year periods were clustered for each 3-month period (MAM and JJA) for the years 1980 to 2000 (Fig. 2).

\subsection{Sea ice area and anomalies}

Time series of the monthly mean sea ice area over the period January 1979 to December 2013 were calculated for three source regions in the Arctic (Fig. 1). These correspond to the Kara Sea $\left(496875 \mathrm{~km}^{2}\right)$, the Laptev Sea $\left(781875 \mathrm{~km}^{2}\right)$, and a subset of the Arctic Ocean $\left(536875 \mathrm{~km}^{2}\right)$. Observations of sea ice concentrations from passive microwave satellite ra-

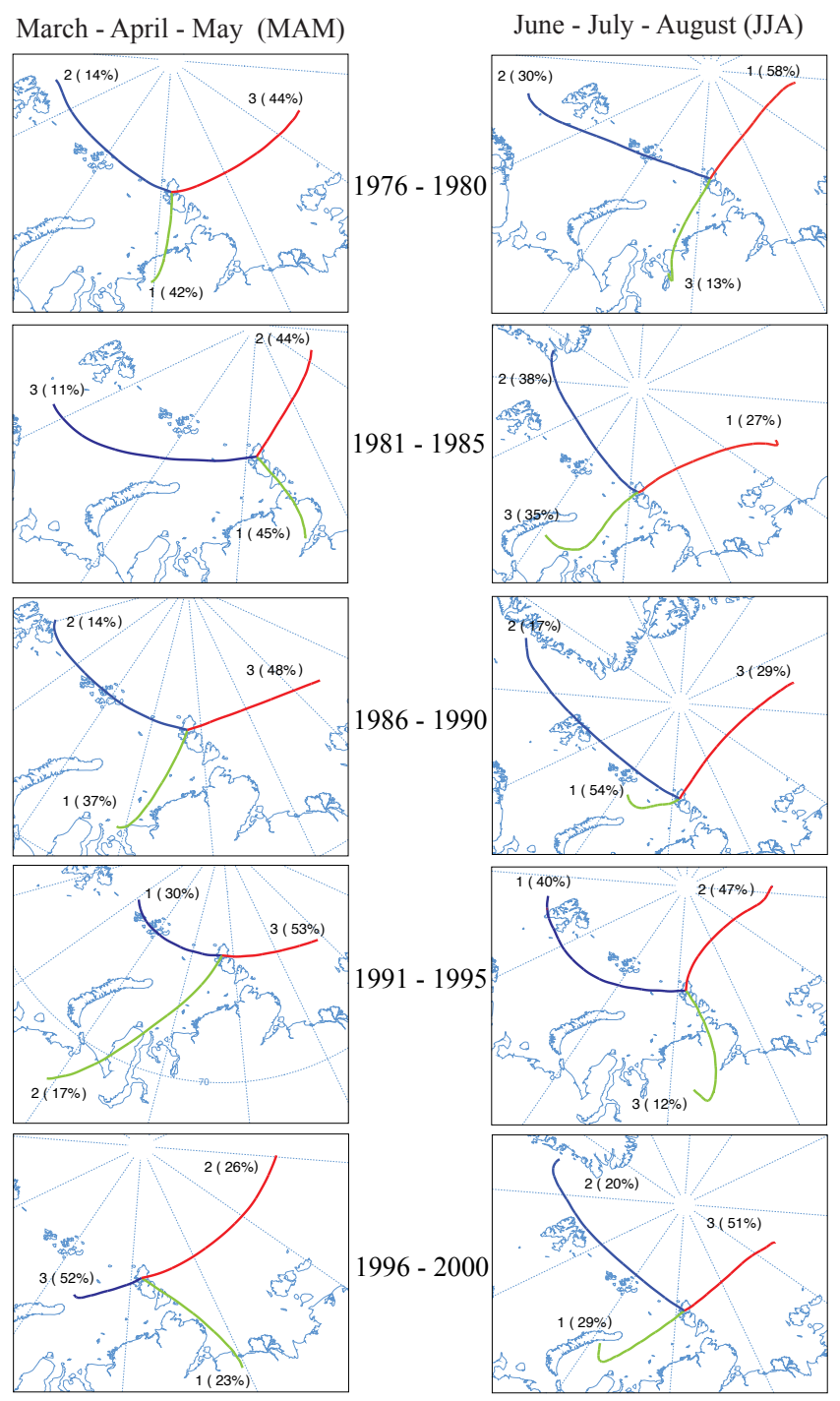

Figure 2. Air mass back trajectories calculated for the period 19762000. Each panel represents the 5-year average for spring (MAM, left column) and summer (JJA, right column) seasons.

diometers were used as input data (Sea Ice Concentrations from Nimbus-7 SMMR and DMSP SSM/I-SSMIS Passive Microwave Data) (Cavalieri et al., 1996, updated yearly). Regional averages were produced for the sea ice concentration data sets which are published at $25 \mathrm{~km}$ grid resolution, resulting in a single sea ice concentration value for each region every day. The time series were resampled to 3-monthly averages for each region and averaged by multiplying the mean sea ice concentration with the area of each region.

Typical uncertainties for sea ice concentration observations are between 5 and $10 \%$, depending upon the time of year (greater uncertainty in summer) and the sea ice concentration range (greater uncertainty for lower ice concentrations). Although averaging over larger areas, such as those designated in Fig. 1, will reduce the relative uncertainty, we 
estimate the uncertainty of the sea ice data presented here to be no greater than $10 \%$.

In addition to the satellite measurements, we compare our results to the data set produced by Polyakov et al. (2003) reporting August sea ice anomalies in the Kara, Laptev, East Siberian and Chukchi Seas. The data set was produced by compiling Russian historical records of fast ice locations in the Arctic seas from ship-based observations, hydrographic surveys and commercial shipping routes and aircraft-based observations. During World War II some missing data (19421945) were reconstructed using statistical regression models.

\section{Results}

\subsection{Trajectories and sea ice area: the Laptev Sea basin influence}

Air mass back trajectories suggest that the Laptev Sea basin is the predominant source for air masses arriving at the Akademii Nauk drill site during springtime (Fig. 2). The percentage of the springtime air masses originating in the Laptev Basin range from a minimum of $44 \%$ (1976-1980) up to $53 \%$ (1991-1995), with the percentage of air masses originating from the Kara Sea and Arctic Ocean regions defined here consistently lower. Hence, we consider the Laptev Sea basin to be the most important source region for the spring climate signal present in the Akademii Nauk ice core. For the summer period the sources are more variable, with the Laptev Sea basin showing a majority of air mass sources in three of the five 5-year periods investigated. During the decade 19811990, the percentage of summer air masses from the Kara Sea exceeds those from the Laptev Sea (in particular between 1986 and 1990); however no associated changes have been detected in climate proxies such as $\delta^{18} \mathrm{O}$ (Opel et al., 2009).

In addition to the back trajectories, we calculate sea ice areas for the three assigned basins of the Arctic Ocean and Laptev and Kara Sea regions. The results clearly demonstrate that the greatest variability of sea ice area occurs in the Laptev Sea for both spring and summer sea ice. In particular the Arctic Ocean region shows very small changes in summer minima, and the production of first-year sea ice is hence negligible compared to the other two basins. Seasonal changes in Kara Sea sea ice area are comparable to those calculated for the Laptev Sea (Fig. 3). However, considering that the air masses arriving at Akademii Nauk in spring and summer originate primarily from the Laptev Sea and that this region displays the greatest seasonal variability in sea ice area, we consider halogen concentration in the Akademii Nauk ice core to be most likely dominated by sea ice variability in the Laptev Sea. Nonetheless we also evaluate the possibility that the Kara Sea is an important secondary source of halogens.

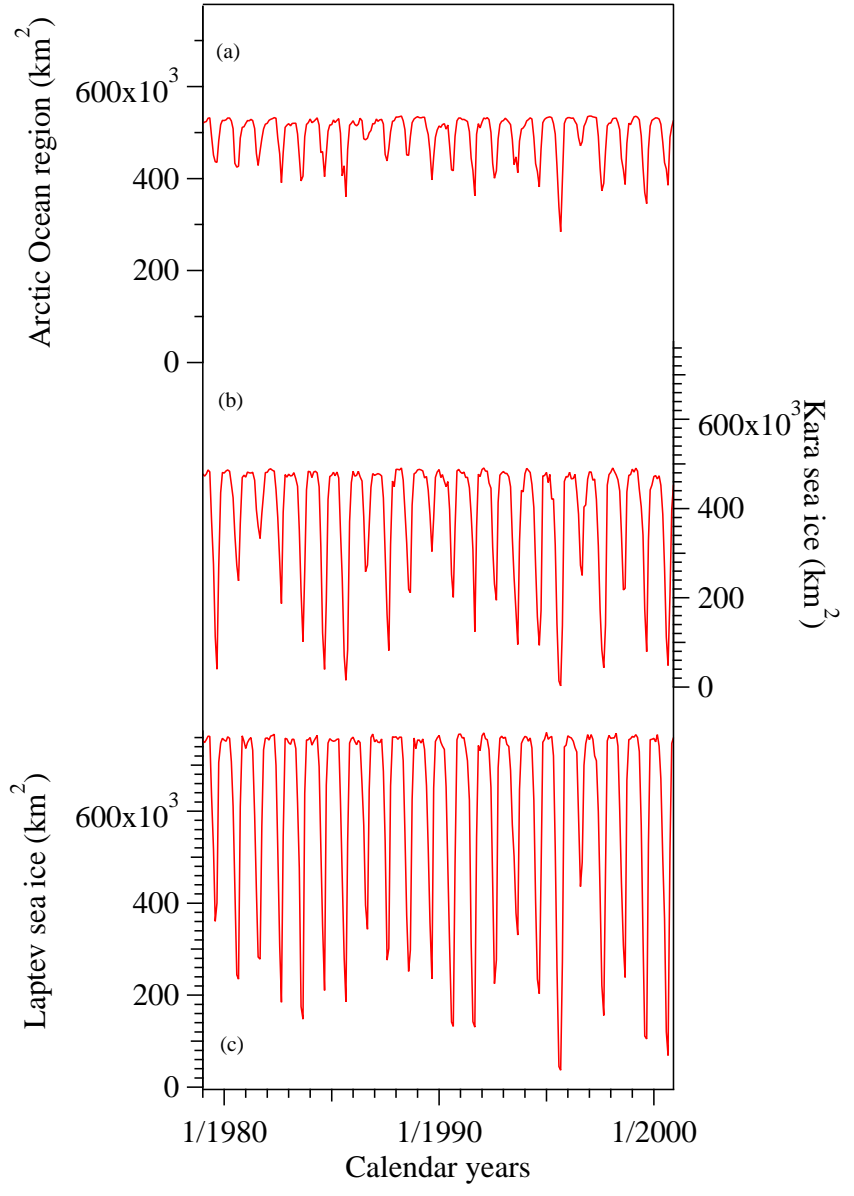

Figure 3. Sea ice area variation in the period 1979-2000 for the three regions defined in Fig. 1: (a) Arctic Ocean, (b) Kara Sea and (c) Laptev Sea. Laptev Sea sea ice shows the greatest seasonal variability.

\subsection{Statistical analysis}

Given the results of the calculated air mass back trajectory and observed sea ice variability, we compare the yearly average values of $\mathrm{Br}_{\mathrm{exc}}$ and I concentrations with summer and spring sea ice of the Laptev and Kara seas. Because of the low variability detected in this part of the Arctic Ocean, this region was excluded from statistical evaluation. Apart from the Polyakov anomalies, the parameters are transformed to the logarithmic scale to reduce their asymmetry and thus improve on the adherence to the normal distribution assumption used in the statistical analyses. Inspection of normal probability plots confirms the absence of departures from the normality for the log-transformed parameters. Furthermore, the series of $\log (\mathrm{I})$ is de-trended by subtracting a least-squaresfit straight line. Autocorrelation and partial autocorrelation plots confirm the absence of serial correlation in the logtransformed parameters and in the detrended $\log (\mathrm{I})$. 
Table 1. Correlations $(r)$ of the detrended $\log (\mathrm{I})$ and $\log \left(\mathrm{Br}_{\text {exc }}\right)$ with the logarithm of the first-year sea ice area in the Laptev and Kara seas for the period 1979-1999 and the Polyakov anomalies in the Laptev and Kara seas for the period 1950-1999 (denoted by an asterisk) (Polyakov et al., 2003). Columns display the $r$ values and $p$ values. Bold numbers indicate the statistically significant correlations. No correlation has been calculated between $\log ($ Brexc) and summer sea ice since the bromine explosion occurs during springtime.

\begin{tabular}{lllll}
\hline & \multicolumn{2}{c}{$\log \left(\mathrm{Br}_{\text {exc }}\right)$} & \multicolumn{2}{c}{$\log (\mathrm{I})$} \\
\cline { 2 - 5 } & $r$ & $p$ value & $r$ & $p$ value \\
\hline Laptev Sea spring & $\mathbf{0 . 4 4}$ & $\mathbf{0 . 0 2 0}$ & $\mathbf{0 . 5 0}$ & $\mathbf{0 . 0 0 9}$ \\
Kara Sea spring & 0.18 & 0.205 & 0.04 & 0.433 \\
Laptev Sea summer & - & - & $\mathbf{0 . 4 9}$ & $\mathbf{0 . 0 1 1}$ \\
Kara Sea summer & - & - & -0.03 & 0.561 \\
Polyakov* - Laptev Sea & $\mathbf{0 . 3 1}$ & $\mathbf{0 . 0 0 9}$ & $\mathbf{0 . 3 2}$ & $\mathbf{0 . 0 1 2}$ \\
Polyakov* - Kara Sea & $\mathbf{0 . 3 4}$ & $\mathbf{0 . 0 1 5}$ & 0.17 & 0.116 \\
\hline
\end{tabular}

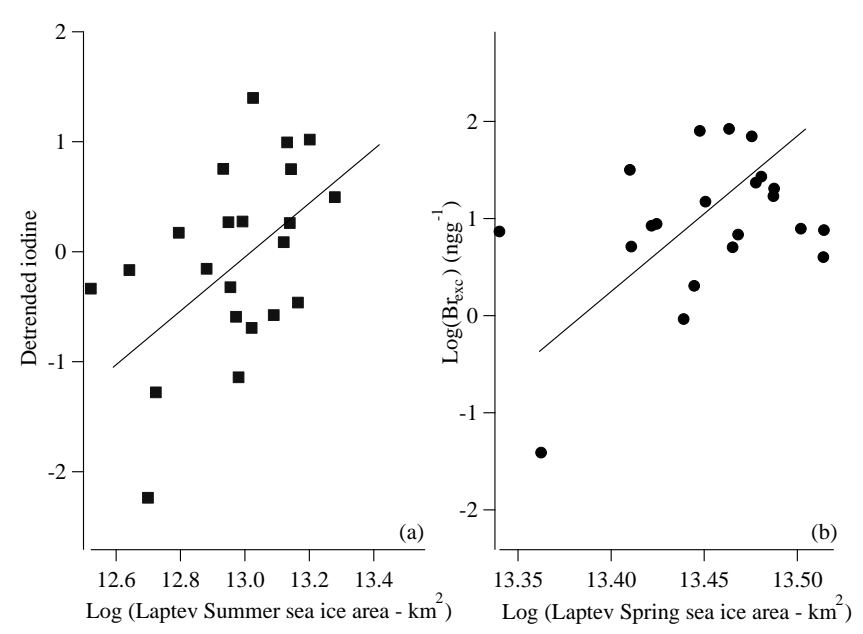

Figure 4. Scatterplot of $\log \left(\mathrm{Br}_{\text {exc }}\right)$ and Laptev Sea spring sea ice area ( $\mathbf{a}$ - black squares) and detrended iodine and Laptev Sea summer sea ice area (b-black circles).

Table 1 lists the correlations of the detrended $\log (\mathrm{I})$ and $\log \left(\mathrm{Br}_{\mathrm{exc}}\right)$ with various calculated parameters of sea ice extent together with the $p$ values based on the unilateral $t$ test for the correlation coefficient. We consider correlations with a $p$ value smaller than 0.05 as an indication of a statistically significant positive correlation. The data support a significant positive correlation between $\log (\mathrm{I})$ and the logarithm of the Laptev Sea sea ice area both in spring $(r=0.50, \mathrm{df}=20$, $p=0.009)$ and summer $(r=0.49, \mathrm{df}=20, p=0.011)$, while there is no evidence of correlation with the Kara Sea sea ice area in either season (Fig. 4a). The results confirm also a positive correlation between $\log \left(\mathrm{Br}_{\text {exc }}\right)$ and the logarithm of the Laptev Sea spring sea ice $(r=0.44, \mathrm{df}=20, p=0.020)$ but not with Kara Sea spring sea ice $(r=0.18, \mathrm{df}=20$, $p=0.205)$ (Fig. 4b).
We also evaluate the correlation between $\log \left(\mathrm{Br}_{\mathrm{exc}}\right)$ and I with the Polyakov anomalies data set. The Polyakov anomalies data set represents the summer (August) sea ice changes in the last century for several Arctic basins, including the Laptev and Kara seas. The obtained results confirm the finding that $\log \left(\mathrm{Br}_{\text {exc }}\right)$ is correlated with Laptev. The correlation between $\log \left(\mathrm{Br}_{\mathrm{exc}}\right)$ and the Polyakov anomalies data set is significant for both Laptev Sea sea ice $(r=0.34$, $\mathrm{df}=48, p$ value $=0.009)$ and Kara Sea sea ice $(r=0.31$, $\mathrm{df}=48, p$ value $=0.015)$. As regards iodine, data indicate a significant correlation between $\log (\mathrm{I})$ and the Polyakov anomalies data for Laptev Sea sea ice $(r=0.32$, df $=48$, $p$ value $=0.012)$ but not for Kara Sea sea ice $(r=0.17$, $\mathrm{df}=48, p$ value $=0.116)$. These results, together with backtrajectory calculation, support the Laptev Sea as the main location of sea ice variability influencing $\mathrm{Br}_{\mathrm{exc}}$ and $\mathrm{I}$ in the Akademii Nauk ice core.

\section{Discussion}

\section{1 $\mathrm{Br}_{\text {exc }}$ and Laptev Sea spring sea ice}

Bromine explosions are defined as the autocatalytic sequence of chemical reactions able to generate gas phase bromine species (such as $\mathrm{BrO}$ ), and they occur mainly above seasonal sea ice (Fig. 5). Bromine explosions lead to enrichment of $\mathrm{Br}$ in snow deposition, well beyond the $\mathrm{Br} / \mathrm{Na}$ ratio observed in seawater. Bromine can also be emitted by other sources, such as biological activity or anthropogenic emissions. In addition heterogeneous reactions on sea salt particles and sea salts on snow or sea ice can contribute to the total emission of $\mathrm{Br}$ from the bromine explosion. However satellite images and previous results suggest that these processes are secondary to the sea-ice-based bromine emission. There are two calculations that can be used to quantify the influence of bromine explosions in snowpack: bromine excess $\left(\mathrm{Br}_{\mathrm{exc}}\right)$ and bromine enrichment $\left(\mathrm{Br}_{\mathrm{enr}}\right)$. Both calculations use the same $\mathrm{Br} / \mathrm{Na}$ seawater concentration ratio of 0.006 (Turekian, 1968). $\mathrm{Br}_{\mathrm{exc}}$ is calculated as $\mathrm{Br}_{\text {exc }}[\mathrm{Br}]-[\mathrm{Na}] \times 0.006$ and indicates how much bromine has been produced by the bromine explosion. $\mathrm{Br}_{\text {enr }}$ is calculated as $\mathrm{Br}_{\text {enr }}=[\mathrm{Br}] /([\mathrm{Na}] \times 0.006)$ and indicates the factor by which bromine has been enriched beyond the seawater ratio. Comparing both $\mathrm{Br}$ indicators $\left(\mathrm{Br}_{\mathrm{exc}}\right.$ and $\mathrm{Br}_{\mathrm{enr}}$ ) reveals that they have a similar trend over the past 50 years, with a peak in the 1970s and 1980s and a sharp decrease in the last decade of the record (Fig. 6). To investigate the connection between $\mathrm{Br}$ and sea ice, we used $\mathrm{Br}_{\text {exc }}$ since it allows quantification of the additional bromine fluxes produced by the bromine explosion. Additionally, the Akademii Nauk ice core was subject to summer melt and hence may be susceptible to artifacts based on the different percolation velocities of $\mathrm{Br}$ and $\mathrm{Na}$. Air mass back-trajectory data indicate the Laptev Sea is the primary springtime source of air masses arriving at Akademii Nauk, so we compare $\mathrm{Br}_{\mathrm{exc}}$ 

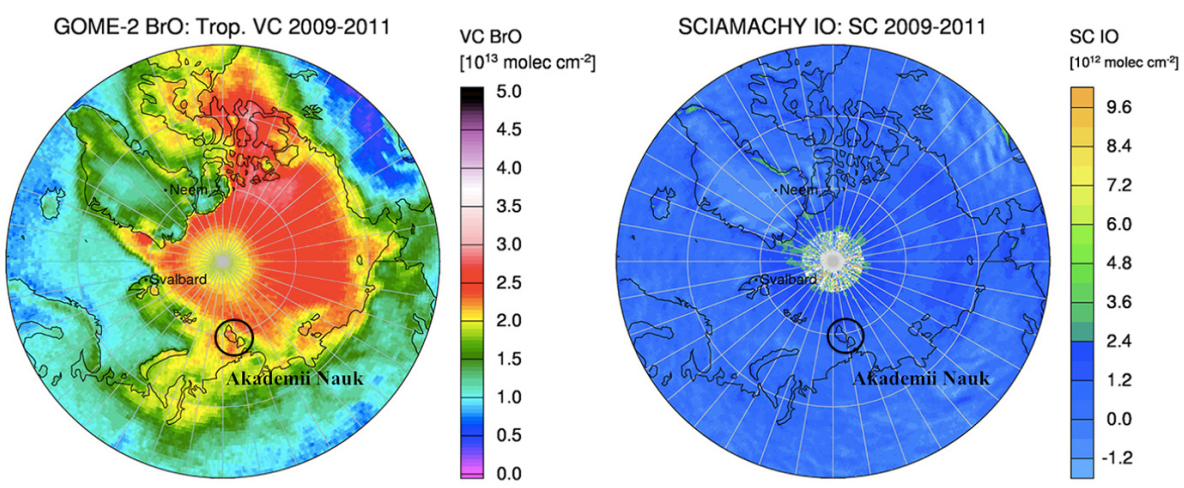

Figure 5. Atmospheric column averages of $\mathrm{BrO}$ and $\mathrm{IO}$ in the Arctic between 2009 and 2011. In the Arctic, IO concentrations are near the limit of detection by satellite (after Spolaor et al., 2014).

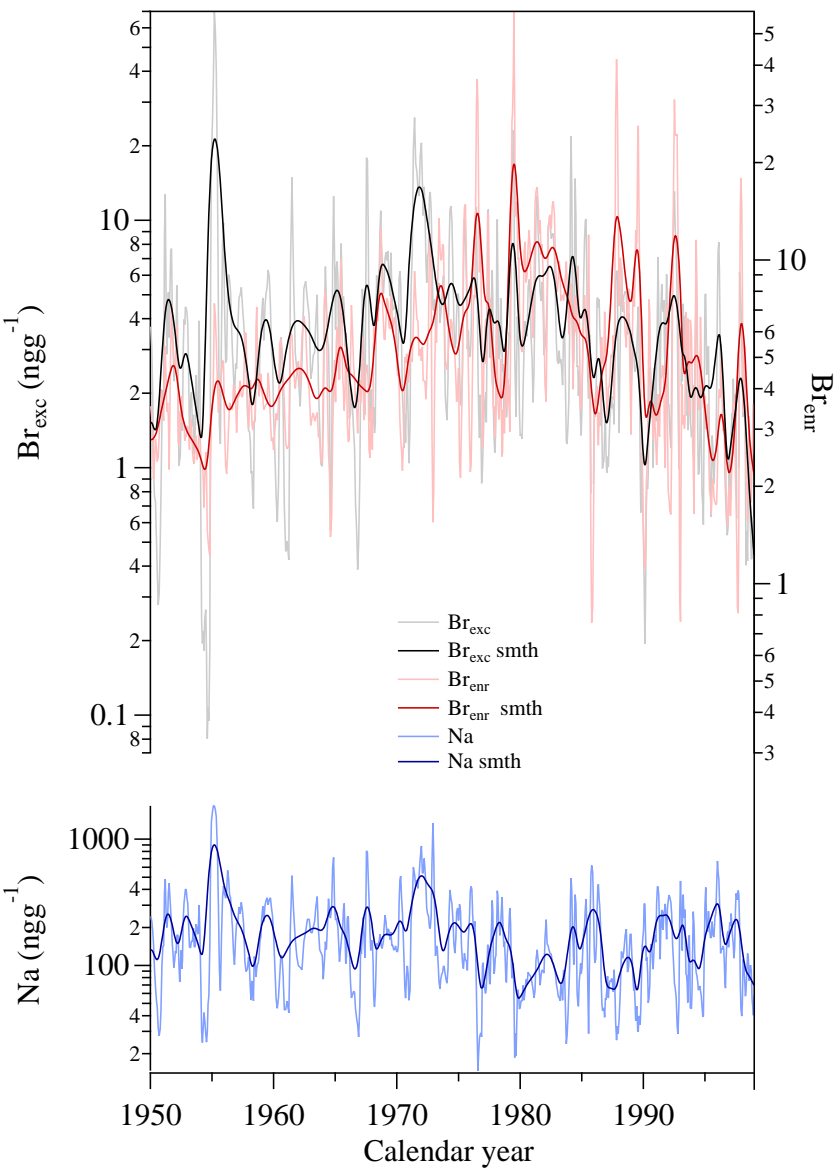

Figure 6. Comparison between bromine excess $\left(\mathrm{Br}_{\mathrm{exc}}\right)$ concentrations, bromine enrichment $\left(\mathrm{Br}_{\mathrm{enr}}\right)$ ratios and sodium $\left(\mathrm{ng} \mathrm{g}^{-1}\right)$ from the Akademii Nauk ice core. Raw (grey line) and 3-year smoothed (black line) $\mathrm{Br}_{\text {exc }}$ concentrations and raw (pink line) and 3-year smoothed (red line) $\mathrm{Br}_{\text {enr }}$ are shown on logarithmic scales. Raw (light blue) and 3-year smoothed (dark blue) sodium data are also shown. with spring sea ice area in the Laptev Sea. It must be noted that bromine explosions are promoted by first-year sea ice (Simpson et al., 2007). Considering the strong sea ice recycling in the Laptev Sea and the small amount of summer sea ice area compared to winter sea ice (Fig. 3), we consider the whole spring sea ice area to be an active site for the bromine explosion. A strong influence of the bromine explosion also is expected due to the observation that only 15 to $30 \%$ of sea ice is present by late summer, implying that almost all spring sea ice is seasonal. Furthermore, Laptev Sea sea ice can be exported by the Transpolar Drift through the Arctic Ocean to the Greenland Sea and North Atlantic, leading to strong recycling of sea ice in the area (Xiao et al., 2013). Comparing the log-transformed $\mathrm{Br}_{\text {exc }}$ and Laptev Sea spring sea ice, we find a positive correlation $(r=0.44)$. Over the period for which observations are available, we note that both spring sea ice area and $\mathrm{Br}_{\mathrm{exc}}$ exhibit a steadily decreasing trend (Fig. 7a). In 1991 in particular, we observe a sharp decrease of spring sea ice followed by decreasing production of $\mathrm{Br}_{\text {exc }}$. The intensity of bromine explosion and the production of $\mathrm{BrO}$ in the Arctic are strongly driven by sea ice presence, in this case spring sea ice. Log-transformed $\mathrm{Br}_{\mathrm{exc}}$ also was compared with a 50-year record of summer ( $\mathrm{Au}-$ gust) sea ice anomalies for the Laptev Basin, calculated by Polyakov et al. (2003) (Fig. 7b). We found a positive correlation between the two data series $(r=0.31)$. We emphasize that the degree of correlation may be influenced by the fact that we are not comparing $\log \left(\mathrm{Br}_{\text {exc }}\right)$ to the sea ice area at the season of peak emission. Although spring and summer sea ice areas may have different short-term trends, the general trend is similar over the decadal period considered here. Although our results suggest that excess of $\mathrm{Br}$ in snow deposition seems mainly driven by the changes in sea ice area, especially first-year sea ice, we also consider other factors that could contribute to the total non-sea salt bromine in the snow deposition. Bromine explosions are catalyzed by acidity and light, and a change in the acidic condition of the Arctic atmosphere could produce a change in the magnitude of bromine activation and hence bromine deposition (Sander et 


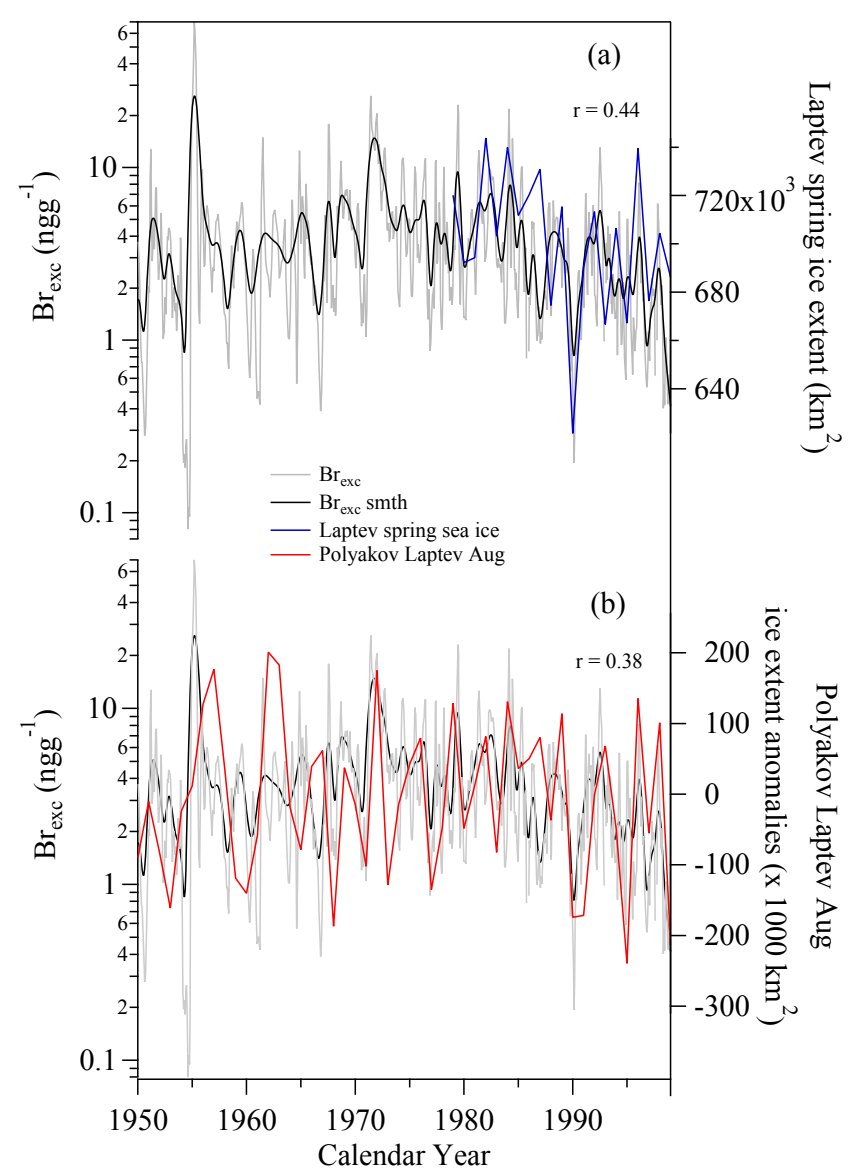

Figure 7. $\mathrm{Br}_{\text {exc }}$ compared with sea ice area during spring and summer in the Laptev Sea region. In both panels, raw (grey line) and 3-year smoothed (black line) $\mathrm{Br}_{\text {exc }}$ data from the Akademii Nauk ice core are shown. The Laptev Sea spring sea ice data are based on satellite observations (blue line, a). Laptev Sea summer sea ice anomalies (red line, b) are from Polyakov et al. (2003).

al., 2006). Other process can interfere with bromine deposition. The recycling of bromine in airborne sea salt aerosols could also impact the bromine concentrations. Quantification of the impacts of acidity changes and other process on $\mathrm{Br}_{\mathrm{exc}}$ (or $\mathrm{Br}_{\text {enr }}$ ) deposition is beyond the scope of this study, and additional studies are necessary to better understand which factors (e.g., sea ice area, acidity, wind pumping, temperature) are the most relevant. However the highly significant correlations and previous research suggest that sea ice is the main driver of $\mathrm{Br}_{\mathrm{exc}}$.

\subsection{Iodine and Laptev Sea summer sea ice}

While the main source of iodine in Antarctica has been attributed to sea ice algae during springtime (Atkinson et al., 2012; Saiz-Lopez et al., 2007, 2015) and recently also to inorganic emissions during wintertime (Granfors et al., 2014), in the Arctic there is a lack of knowledge regarding iodine sources. One of the main barriers to identifying Arctic io-

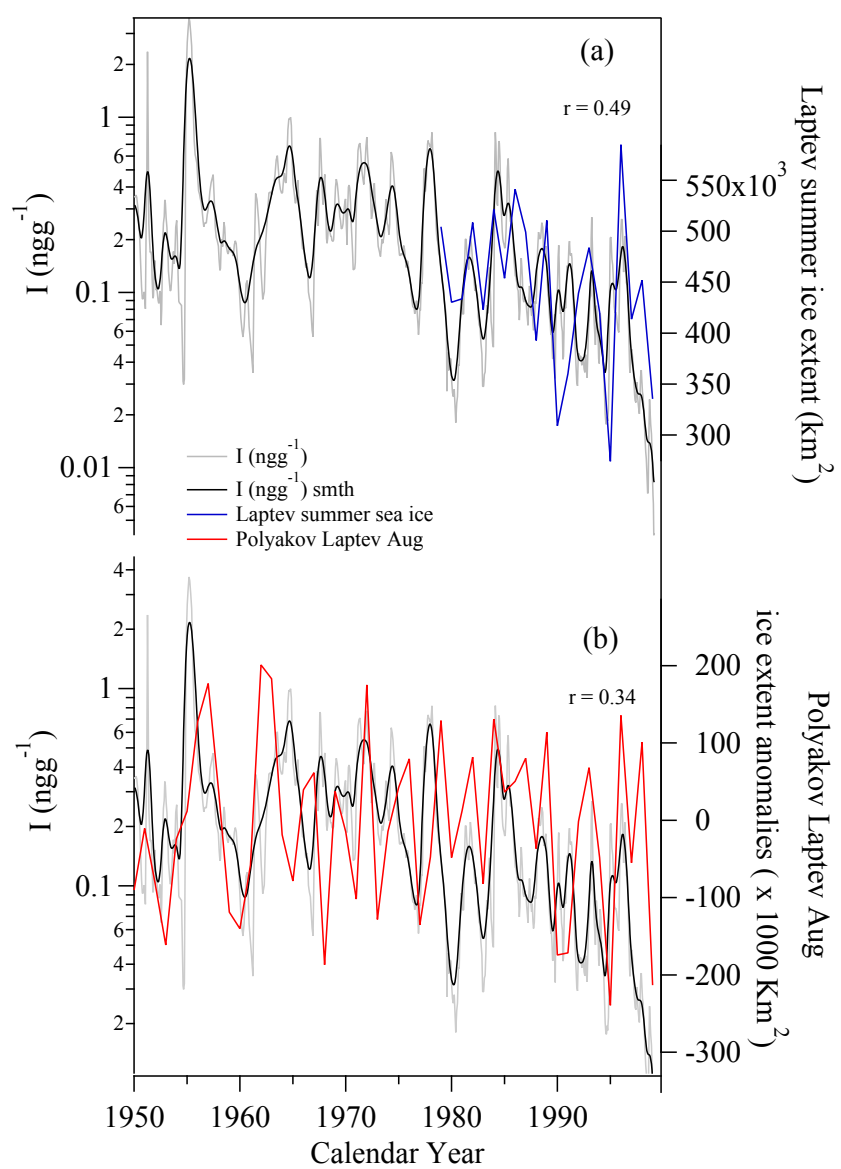

Figure 8. Iodine compared with Laptev Sea summer sea ice area. In both panels, raw (grey line) and 3-year smoothed (black line) (I) data from the Akademii Nauk ice core are shown. The Laptev Sea summer sea ice data are based on satellite observations (blue line, a) and the reconstruction of Polyakov et al. (2003) (red line, b).

dine sources is that the atmospheric concentrations of IO are close to satellite detection limits (Fig. 5). Iodine could be emitted also by heterogeneous reactions on sea ice, snowpack, or marine aerosol surfaces, but the general idea remains that the control of iodine atmospheric concentration is due to biological activities associated with sea ice. The first measurements of iodine in Arctic aerosols (Sturges and Barrie, 1988) found increasing concentrations during late spring and summer. More recently Mahajan et al. (2010) detected iodine emissions in the form of IO, related to the presence of polynyas or areas free of sea ice over Hudson Bay, Canada. These open water areas were identified as hot spots for iodine emission. Arctic sea ice is thicker and less permeable than Antarctic sea ice, constituting a barrier between the ocean and the atmosphere (Zhou et al., 2013). In this case it is likely that gas phase iodine produced from sea ice algae could escape only from sea ice leads (cracks) or the open-ocean surface (Saiz-Lopez et al., 2015). The Akademii Nauk iodine signal is positively correlated with satellite observations of 
Laptev Sea summer sea ice $(r=0.49$, Table 1 and Fig. 8a) and with spring sea ice $(r=0.50)$. Concentrations of I also have been compared with summer (August) sea ice anomalies for the Laptev Basin calculated by Polyakov et al. (2003) (Fig. 8b). A significant positive correlation $(r=0.32$, Table 1) was observed also in this case. No significant correlation was observed with summer or spring sea ice area in the Kara Sea (Table 1), supporting the back-trajectory analysis data. These results are consistent with iodine concentrations from a snow pit sampled at the NEEM (North Greenland Eemian Ice Drilling) ice core site in northwest Greenland. The NEEM record displayed peak iodine concentrations in summer (Spolaor et al., 2014), although only three annual cycles were sampled. In contrast, iodine concentrations from Svalbard were more consistent with spring sea ice area (Spolaor et al., 2013a). The results from Svalbard must be evaluated with caution because seasonal variability is less clear in the Svalbard records and the influence of summer melting and iodine re-emission may be more significant than for the Akademii Nauk ice core. The summer peak of iodine concentrations found in Arctic snow and ice may depend upon both the production of iodine by sea ice algae and processes that control release of iodine to the atmosphere. Arctic sea ice is an effective barrier to gas exchange in the ocean-atmosphere system especially in winter, when there is low ice permeability and minimal convection of Arctic waters (Zhou et al., 2013). Ice permeability follows Arctic temperatures, with maximum permeability in summer and particularly when the sea ice is warmer than $-5^{\circ} \mathrm{C}$. Water convection is greatest during spring, driven by an unstable brine density profile. As suggested for the Antarctic (Saiz-Lopez et al., 2015), fracturing is an additional process that may enhance gas exchange, and hence iodine emission from the Arctic Seas, particularly in the highly dynamic Laptev Sea. Phytoplankton blooms occur mainly in late spring and summer (Ardyna et al., 2013; Arrigo et al., 2012), responding to the availability of nutrients and the limited penetration of light through thick winter sea ice. These factors ensure that the most efficient season for production and emission of iodine is the Arctic summer. In summer, the decreased sea ice thickness, increased sea ice fracturing and permeability, and enhanced light penetration and nutrient availability could create conditions necessary to sustain blooms of sea ice algae responsible for IO production (Arrigo et al., 2012; Allan et al., 2015). In years of decreased Arctic sea ice area, the available substratum for growing algae is reduced and hence IO production is inhibited. This explanation fits well with the data available from Greenland (Spolaor et al., 2014) and presented here for the Akademii Nauk ice core. Satellite measurements of Arctic IO concentrations exceed detection limits only in the summer, and at that time of maximum IO concentrations above summer sea ice. However, these results can only be used as indications. Improved sensitivity of satellite-borne instruments would greatly enhance the detection and seasonal variability of IO emission sources in the Arctic.

\section{Conclusions}

The halogens iodine and bromine reported here from the Akademii Nauk ice core from Severnaya Zemlya offer a new perspective on the variability of sea ice extent in the Arctic. This work follows on previous work to suggest a connection of bromine and iodine chemistry with sea ice changes (Spolaor et al., 2013a, b, 2014). In particular, $\mathrm{Br}_{\text {exc }}$ and $\mathrm{Br}_{\mathrm{enr}}$ have been linked to seasonal sea ice area, and here we report a connection between ice-core $\mathrm{Br}_{\text {exc }}$ and spring sea ice in the Laptev Sea largely because almost all Laptev Sea spring sea ice is seasonal (approximately $80 \%$ ) and so undergoes continuous renewal. Ice core iodine appears to be connected with the summer sea ice area; however, its sources are suggested to be biologically mediated, which makes the interpretation more difficult, and atmospheric concentrations of IO in the Arctic are close to satellite detection limits, limiting the accurate characterization of IO emission sources. Further studies are necessary to better identify the seasonal variability of this element and the impact of acidity on bromine reactivity in the Arctic. However, the significant correlation between nss$\mathrm{Br}$ and sea ice during the last 50 years in the Akademii Nauk ice core record suggests that the nss- $\mathrm{Br}$ record primarily reflects changing sea ice conditions in the Laptev Sea, bringing important new information for the use of halogens in paleoclimate studies and suggesting that the Akademii Nauk ice core may be a key archive for reconstructing late-Holocene sea ice variations in the Russian Arctic.

\section{The Supplement related to this article is available online at doi:10.5194/tc-10-245-2016-supplement.}

Acknowledgements. This study contributes to the Eurasian Arctic Ice $4 \mathrm{k}$ project and was supported by the Deutsche Forschungsgemeinschaft (grant OP 217/2-1 awarded to Thomas Opel). The drilling project on the Akademii Nauk ice cap was funded by the German Ministry of Education and Research (BMBF research project 03PL 027A). Analysis and interpretation of the Akademii Nauk ice core at the Desert Research Institute was funded by US National Science Foundation grant 1023672. The research leading to these results received funding from the European Research Council under the European Community's Seventh Framework Programme (FP7/2007-2013)/ERC grant agreement no. 610055. We thank the University of Bremen, supported by the State of Bremen; the German Aerospace Center, DLR; and the European Space Agency for the satellite $\mathrm{BrO}$ imagines.

Edited by: F. Dominé 


\section{References}

Abram, N. J., Wolff, E. W., and Curran, M. A. J.: A review of sea ice proxy information from polar ice cores, Quat. Sci. Rev., 79, 168-183, doi:10.1016/j.quascirev.2013.01.011, 2013.

Allan, J. D., Williams, P. I., Najera, J., Whitehead, J. D., Flynn, M. J., Taylor, J. W., Liu, D., Darbyshire, E., Carpenter, L. J., Chance, R., Andrews, S. J., Hackenberg, S. C., and McFiggans, G.: Iodine observed in new particle formation events in the Arctic atmosphere during ACCACIA, Atmos. Chem. Phys., 15, 55995609, doi:10.5194/acp-15-5599-2015, 2015.

Ardyna, M., Babin, M., Gosselin, M., Devred, E., Beìlanger, S., Matsuoka, A., and Tremblay, J.-E.: Parameterization of vertical chlorophyll a in the Arctic Ocean: impact of the subsurface chlorophyll maximum on regional, seasonal, and annual primary production estimates, Biogeosciences, 10, 4383-4404, doi:10.5194/bg-10-4383-2013, 2013.

Arrigo, K. R., Perovich, D. K., Pickart, R. S., Brown, Z. W., van Dijken, G. L., Lowry, K. E., Mills, M. M., Palmer, M. A., Balch, W. M., Bahr, F., Bates, N. R., Benitez-Nelson, C., Bowler, B., 25 Brownlee, E., Ehn, J. K., Frey, K. E., Garley, R., Laney, S. R., Lubelczyk, L., Mathis, J., Mat- suoka, A., Mitchell, G. B., Moore, G. W. K., Ortega-Retuerta, E., Pal, S., Polashenski, C. M., Reynolds, R. A., Schieber, B., Sosik, H. M., Stephens, M., and Swift, J. H.: Massive Phytoplankton Blooms Under Arctic Sea Ice, Science, 336, 1408, doi:10.1126/science.1215065, 2012.

Atkinson, H. M., Huang, R.-J., Chance, R., Roscoe, H. K., Hughes, C., Davison, B., Schönhardt, A., Mahajan, A. S., Saiz-Lopez, A., Hoffmann, T., and Liss, P. S.: Iodine emissions from the sea ice of the Weddell Sea, Atmos. Chem. Phys., 12, 11229-11244, doi:10.5194/acp-12-11229-2012, 2012.

Barrie, L. A., Yi, Y., Leaitch, W. R., Lohmann, U., Kasibhatla, P., Roelofs, G. J., Wilson, J., McGovern, F., Benkovitz, C., Melieres, M. A., Law, K., Prospero, J., Kritz, M., Bergmann, D., Bridgeman, C., Chin, M., Christensen, J., Easter, R., Feichter, J., Land, C., Jeuken, A., Kjellstrom, E., Koch, D., and Rasch, P.: A comparison of large-scale atmospheric sulphate aerosol models (COSAM): overview and highlights, Tellus B, 53, 615-645, 2001.

Belt, S. T., Masseì, G., Rowland, S. J., Poulin, M., Michel, C., and LeBlanc, B.: A novel chemical fossil of palaeo sea ice: IP25, Organic Geochemistry, 38, 16-27, 2007.

Cavalieri, D. J., Parkinson, C. L., Gloersen, P., and Zwally, H. J.: Sea Ice Concentrations from Nimbus-7 SMMR and DMSP SSM/ISSMIS Passive Microwave Data, Version 1. Boulder, Colorado USA, NASA National Snow and Ice Data Center Distributed Active Archive Center, doi:10.5067/8GQ8LZQVL0VL, updated yearly, 1996.

Comiso, J. C.: Large Decadal Decline of the Arctic Multiyear Ice Cover, J. Climate, 25, 1176-1193, doi:10.1175/jcli-d-1100113.1, 2011.

Curran, M. A., Van Ommen, T. D., Morgan, V. I., Phillips, K. L., and Palmer., M. R.: Ice core evidence for Antarctic sea ice decline since the 1950s, Science, 302, 1203-1206, 2003.

Darby, D. A.: Sources of sediment found in sea ice from the western Arctic Ocean, new insights into processes of entrainment and drift patterns, J. Geophys. Res., 108, 3257, doi:10.1029/2002JC001350, 2003.

de Gois, J., Vallelonga, P., Spolaor, A., Devulder, V., Borges, D. G., and Vanhaecke, F.: Bromine isotope ratio measurements in sea- water by multi-collector inductively coupled plasma-mass spectrometry with a conventional sample introduction system, Anal. Bioanal. Chem., 1-8, doi:10.1007/s00216-015-8820-1, 2015.

Dieckmann, G. S. and Hellmer, H. H.: The importance of sea ice: An overview in Sea ice, edited by: Dieckmann, G. S., Blackwell Publishing Ltd, UK, 1-22, 2010.

Divine, D. V., and Dick, C.: Historical variability of sea ice edge position in the Nordic Seas, J. Geophys. Res.-Ocean., 111, C01001, doi:10.1029/2004jc002851, 2006.

Draxler, R. R. and Hess, G. D.: An overview of the HYSPLIT_4 modeling system of trajectories, dispersion, and deposition, Aust. Meteor. Mag., 47, 295-308, 1998.

Francis, J. A., Chan, W., Leathers, D. J., Miller, J. R., and Veron, D. E.: Winter Northern Hemisphere weather patterns remember summer Arctic sea-ice extent, Geophys. Res. Lett., 36, L07503, doi:10.1029/2009GL037274, 2009.

Fritzsche, D., Wilhelms, F., Savatyugin, L. M., Pinglot, J. F., Meyer, H., Hubberten, H. W., and Miller, H.: A new deep ice core from Akademii Nauk ice cap, Severnaya Zemlya, Eurasian Arctic: first results, Ann. Glaciol., 35, 25-28, 2002.

Fritzsche, D., Schütt, R., Meyer, H., Miller, H., Wilhelms, F., Opel, T., and Savatyugin, L. M.: A 275 year ice-core record from Akademii Nauk ice cap, Severnaya Zemlya, Russian Arctic, Ann. Glaciol., 42, 361-366, 2005.

Granfors, A., Ahnoff, M. M., Mills, M. M., and Abrahamsson, K.: Organic iodine in Antarctic sea ice: A comparison between winter in the Weddell Sea and summer in the Amundsen Sea, J. Geophys. Res., 119, 2276-2291, doi:10.1002/2014JG002727, 2014.

Holland, M. M., Bitz, C. M., Eby, M., and Weaver, A. J.: The Role of Ice-Ocean Interactions in the Variability of the North Atlantic Thermohaline Circulation, J. Climate, 14, 656-675, 2001.

Isaksson, E., Kekonen, T., Moore, J., and Mulvaney, R.: The methanesulfonic acid (MSA) record in a Svalbard ice core, Ann. Glaciol., 42, 345-351, 2005.

Kinnard, C., Zdanowicz, C. M., Fisher, D. A., Isaksson, E., De Vernal, A., and Thompson, L. G.: Reconstructed changes in Arctic sea ice over the past 1,450 years, Nature, 479, 509-512, 2011.

Levine, J. G., Yang, X., Jones, A. E., and Wolff, E. W.: Sea salt as an ice core proxy for past sea ice extent: A processbased model study, J. Geophys. Res.-Atmos., 119, 5737-5756, doi:10.1002/2013JD020925, 2014.

Lisitzin, A. P.: Sea-ice and Iceberg Sedimentation in the Ocean: Recent and Past, edited by: Springer-Verlag, Berlin, Heidelberg, doi:10.1007/978-3-642-55905-1, 2002.

Mahajan, A. S., Shaw, M., Oetjen, H., Hornsby, K. E., Carpenter, L. J., Kaleschke, L., Tian-Kunze, X., Lee, J. D., Moller, S. J., Edwards, P., Commane, R., Ingham, T., Heard, D. E., and Plane, J. M. C.: Evidence of reactive iodine chemistry in the Arctic boundary layer, J. Geophys. Res.-Atmos., 115, D20303, doi:10.1029/2009jd013665, 2010.

Maselli, O., Fritzche D, L., L., J., M., and Meyer, H.: Comparison of water isotope ratio determinations using two cavity ringdown instruments and classical mass spectrometry in continuous ice-core analysis, Isotopes Environ. Health Stud., 49, 387-398, doi:10.1080/10256016.2013.781598, 2013.

McConnell, J. R., Lamorey, G. W., Lambert, S. W., and Taylor, K. C.: Continuous Ice-Core Chemical Analyses Using Inductively Coupled Plasma Mass Spectrometry, Environ. Sci. Technol., 36, 7-11, doi:10.1021/es011088z, 2002. 
McConnell, J. R., Edwards, R., Kok, G. L., Flanner, M. G., Zender, C. S., Saltzman, E. S., Banta, J. R., Pasteris, D. R., Carter, M. M., and Kahl, J. D. W.: 20th-Century Industrial Black Carbon Emissions Altered Arctic Climate Forcing, Science, 317, 13811384, 2007.

McConnell, J. R., Maselli, O. J., Sigl, M., Vallelonga, P., Neumann, T., Anschütz, H., Bales, R. C., Curran, M. A. J., Das, S. B., Edwards, R., Kipfstuhl, S., Layman, L., and Thomas, E. R.: Antarctic-wide array of high-resolution ice core records reveals pervasive lead pollution began in 1889 and persists today, Sci. Rep., 4, 5848 pp., doi:10.1038/srep05848, 2014.

Müller, J., Masse, G., Stein, R., and Belt, S. T.: Variability of sea-ice conditions in the Fram Strait over the past 30,000 years, Nature Geosci., 2, 772-776, 2009.

Opel, T., Fritzsche, D., Meyer, H., Schütt, R., Weiler, K., Ruth, U., Wilhelms, F., and Fischer, H.: 115 year ice-core data from Akademii Nauk ice cap, Severnaya Zemlya: high-resolution record of Eurasian Arctic climate change, 55, 21-31, 2009.

Opel, T., Fritzsche, D., and Meyer, H.: Eurasian Arctic climate over the past millennium as recorded in the Akademii Nauk ice core (Severnaya Zemlya), Clim. Past, 9, 2379-2389, doi:10.5194/cp9-2379-2013, 2013.

Pasteris, D. R., McConnell, J. R., Das, S. B., Criscitiello, A. S., Evans, M. J., Maselli, O. J., Sigl, M., and Layman, L.: Seasonally resolved ice core records from West Antarctica indicate a sea ice source of sea-salt aerosol and a biomass burning source of ammonium, J. Geophys. Res.-Atmos., 119, 91689182, doi:10.1002/2013jd020720, 2014.

Petit, J. R., Jouzel, J., Raynaud, D., Barkov, N. I., Barnola, J. M., Basile, I., Bender, M., Chappellaz, J., Davis, M., Delaygue, G., Delmotte, M., Kotlyakov, V. M., Legrand, M., Lipenkov, V. Y., Lorius, C., Pepin, L., Ritz, C., Saltzman, E., and Stievenard, M.: Climate and atmospheric history of the past 420,000 years from the Vostok ice core, Antarctica, Nature, 399, 429-436, 1999.

Pohjola, V. A., Moore, J. C., Isaksson, E., Jauhiainen, T., Van de Wal, R. S. W., Martma, T., Meijer, H. A. J., and Vaikmae, R.: Effect of periodic melting on geochemical and isotopic signals in an ice core from Lomonosovfonna, Svalbard, J. Geophys. Res. Atmos., 107, 1-14, 2002.

Polyak, L., Alley, R. B., Andrews, J. T., Brigham-Grette, J., Cronin, T. M., Darby, D. A., Dyke, A. S., Fitzpatrick, J. J., Funder, S., Holland, M., Jennings, A. E., Miller, G. H., O'Regan, M., Savelle, J., Serreze, M., St. John, K., White, J. W. C., and Wolff, E.: History of sea ice in the Arctic, Quat. Sci. Rev., 29, 17571778, 2010.

Polyakov, I. V., Alekseev, G. V., Bekryaev, R. V., Bhatt, U. S., Colony, R., Johnson, M. A., Karklin, V. P., Walsh, D., and Yulin, A. V.: Long-term ice variability in Arctic marginal seas, J. Climate, 16, 2078-2085, 2003.

Pratt, K. A., Custard, K. D., Shepson, P. B., Douglas, T. A., Pohler, D., General, S., Zielcke, J., Simpson, W. R., Platt, U., Tanner, D. J., Gregory Huey, L., Carlsen, M., and Stirm, B. H.: Photochemical production of molecular bromine in Arctic surface snowpacks, Nature Geosci., 6, 351-356, doi:10.1038/ngeo1779, 2013., 2013.

Röthlisberger, R., Crosta, X., Abram, N. J., Armand, L., and Wolff, E. W.: Potential and limitations of marine and ice core sea ice proxies: an example from the Indian Ocean sector, Quat. Sci. Rev., 29, 296-302, 2010.
Saiz-Lopez, A., Mahajan, A. S., Salmon, R. A., Bauguitte, S. J. B., Jones, A. E., Roscoe, H. K., and Plane, J. M. C.: Boundary Layer Halogens in Coastal Antarctica, Science, 317, 348-351, 2007.

Saiz-Lopez, A., Blaszczak-Boxe, C. S., and Carpenter, L. J.: A mechanism for biologically induced iodine emissions from sea ice, Atmos. Chem. Phys., 15, 9731-9746, doi:10.5194/acp-159731-2015, 2015.

Sander, R., Burrows, J., and Kaleschke, L.: Carbonate precipitation in brine \&ndash; a potential trigger for tropospheric ozone depletion events, Atmos. Chem. Phys., 6, 4653-4658, doi:10.5194/acp-6-4653-2006, 2006.

Schonhardt, A., Begoin, M., Richter, A., Wittrock, F., Kaleschke, L., Gomez Martin, J. C., and Burrows, J. P.: Simultaneous satellite observations of IO and $\mathrm{BrO}$ over Antarctica, Atmos. Chem. Phys., 12, 6565-6580, doi:10.5194/acp-12-6565-2012, 2012.

Sigl, M., McConnell, J. R., Toohey, M., Curran, M., Das, S. B., Edwards, R., Isaksson, E., Kawamura, K., Kipfstuhl, S., Kruger, K., Layman, L., Maselli, O. J., Motizuki, Y., Motoyama, H., Pasteris, D. R., and Severi, M.: Insights from Antarctica on volcanic forcing during the Common Era, Nature Clim. Change, 4, 693-697, doi:10.1038/nclimate2293, 2014.

Simpson, W. R., Carlson, D., Hoenninger, G. n. G., Douglas, T. A., Sturm, M., Perovich, D., and Platt, U.: First-year sea-ice contact predicts bromine monoxide $(\mathrm{BrO})$ levels at Barrow, Alaska better than potential frost flower contact, Atmos. Chem. Phys., 7, 621627, doi:10.5194/acp-7-621-2007, 2007.

Simpson, W. R., Brown, S. S., Saiz-Lopez, A., Thornton, J. A., and Glasow, R. v.: Tropospheric Halogen Chemistry: Sources, Cycling, and Impacts, Chem. Rev., 115, 4035-4062, doi:10.1021/cr5006638, 2015.

Spolaor, A., Gabrieli, J., Martma, T., Kohler, J., Björkman, M. B., Isaksson, E., Varin, C., Vallelonga, P., Plane, J. M. C., and Barbante, C.: Sea ice dynamics influence halogen deposition to Svalbard, The Cryosphere, 7, 1645-1658, doi:10.5194/tc-71645-2013, 2013a.

Spolaor, A., Vallelonga, P., Plane, J. M. C., Kehrwald, N., Gabrieli, J., Varin, C., Turetta, C., Cozzi, G., Kumar, R., Boutron, C., and Barbante, C.: Halogen species record Antarctic sea ice extent over glacial-interglacial periods, Atmos. Chem. Phys., 13, 66236635, doi:10.5194/acp-13-6623-2013, 2013b.

Spolaor, A., Vallelonga, P., Gabrieli, J., Martma, T., Björkman, M. P., Isaksson, E., Cozzi, G., Turetta, C., Kjær, H. A., Curran, M. A. J., Moy, A. D., Schönhardt, A., Blechschmidt, A. M., Burrows, J. P., Plane, J. M. C., and Barbante, C.: Seasonality of halogen deposition in polar snow and ice, Atmos. Chem. Phys., 14, 96139622, doi:10.5194/acp-14-9613-2014, 2014.

Stroeve, J., Holland, M. M., Meier, W., Scambos, T., and Serreze, M.: Arctic sea ice decline: Faster than forecast, Geophys. Res. Lett., 34, L09501, doi:10.1029/2007GL029703, 2007.

Sturges, W. T. and Harrison, R. M.: Bromine in marine aerosols and the origin, nature and quantity of natural atmospheric bromine, Atmospheric Environment (1967), 20, 1485-1496, 1986.

Sturges, W. T. and Barrie, L. A.: Chlorine, Bromine and Iodine in arctic aerosols, Atmos. Environ., 22, 1179-1194, doi:10.1016/0004-6981(88)90349-6, 1988.

Turekian, K. K.: Oceans, edited by: Englewood, C., NJ, PrenticeHall, 1968.

Turner, J., Bracegirdle, T., Phillips, T., Marshall, G. J., and Hosking, J. S.: An Initial Assessment of Antarctic Sea Ice Extent in 
the CMIP5 Models, J. Climate, doi:10.1175/jcli-d-12-00068.1, in press, 2012.

Vinje, T.: Anomalies and Trends of Sea-Ice Extent and Atmospheric Circulation in the Nordic Seas during the Period 1864-1998, J. Climate, 14, 255-267, doi:10.1175/15200442(2001)014<0255:aatosi>2.0.CO;2, 2001.

Vogt, R., Crutzen, P. J., and Sander, R.: A mechanism for halogen release from sea-salt aerosol in the remote marine boundary layer, Nature, 383, 327-330, 1996.

Weiler, K., Fischer, H., Fritzsche, D., Ruth, U., Wilhelms, F., and Miller, H.: Glaciochemical reconnaissance of a new ice core from Severnaya Zemlya, Eurasian Arctic, Ann. Glaciol., 51, 64-74, 2005.

Wolff, E. W., Fischer, H., Fundel, F., Ruth, U., Twarloh, B., Littot, G. C., Mulvaney, R., Rothlisberger, R., de Angelis, M., Boutron, C. F., Hansson, M., Jonsell, U., Hutterli, M. A., Lambert, F., Kaufmann, P., Stauffer, B., Stocker, T. F., Steffensen, J. P., Bigler, M., Siggaard-Andersen, M. L., Udisti, R., Becagli, S., Castellano, E., Severi, M., Wagenbach, D., Barbante, C., Gabrielli, P., and Gaspari, V.: Southern Ocean sea-ice extent, productivity and iron flux over the past eight glacial cycles, Nature, 440, 491-496, 2006.
Wolff, E. W., Barbante, C., Becagli, S., Bigler, M., Boutron, C. F., Castellano, E., De Angelis, M., Federer, U., Fischer, H., and Fundel, F.: Changes in environment over the last 800,000 years from chemical analysis of the EPICA Dome C ice core, Quat. Sci. Rev., 29, 285-295, 2010.

Xiao, X., Fahl, K., and Stein, R.: Biomarker distributions in surface sediments from the Kara and Laptev seas (Arctic Ocean): indicators for organic-carbon sources and sea-ice coverage, Quat. Sci. Rev., 79, 40-52, 2013.

Zhou, J., Delille, B., Eicken, H., Vancoppenolle, M., Brabant, F., Carnat, G., Geilfus, N.-X., Papakyriakou, T., Heinesch, B., and Tison, J.-L.: Physical and biogeochemical properties in landfast sea ice (Barrow, Alaska): Insights on brine and gas dynamics across seasons, J. Geophys. Res.-Ocean., 118, 3172-3189, doi:10.1002/jgrc.20232, 2013. 